IRSH 52 (2007), pp. 209-223 DOI: I0.1017/S0020859007003203

(C) 2007 Internationaal Instituut voor Sociale Geschiedenis

\title{
Jokes in a Garment Workshop in Hanoi: How Does Humour Foster the Perception of Community in Social Movements?
}

\author{
NGHiEM Lien HuONG
}

Summary: This article will demonstrate how jokes are used to foster the perception of community among workers on the shopfloor of a garment workshop in Hanoi, Vietnam. Although jokes cannot be considered as overt resistance on the part of workers, by containing an element of collective reality and desire a sense of collectivity among the workers is heightened. The article will analyse two jokes in their embedded contexts to highlight the importance of humour in the workers' struggle against management.

Humour in the workplace is one form of covert resistance against management. ${ }^{\mathrm{I}}$ Although humour cannot be considered as a factor contributing to the emergence of a vibrant social movement, the collective nature of humour in the workplace can foster the perception of community in the social movement of the working class. Despite the fact that jokes can be told by, or their contents refer to, just one or two people, they always reflect everyone's experience. ${ }^{2}$ Moreover, the way jokes are circulated among workers strengthens their solidarity as a group vis-à-vis management. ${ }^{3}$ I intend to analyse two separate jokes in terms not only of their content but also of who told the jokes and in what context; I will also examine the possible origins of the jokes and their effects.

The first joke is derived from imagining how workers might have answered questions put to them by labour inspectors, if those workers had been interviewed by those inspectors. The second joke concerns workers' pretence of collapsing on the shopfloor and the reactions of colleagues and the workshop's management to the "accidents". Both stories reflect a collective reality: a high-intensity job, long working hours, and an

I. Yiannis Gabriel, “The Unmanaged Organization: Stories, Fantasies and Subjectivity", Organization Studies, I6 (1995), pp. 477-50I.

2. R. Samuel and P. Thompson (eds), The Myths We Live By (London [etc.], 1990).

3. D.S. Simmons, "The Nature of the Organizational Grapevine", Supervisory Management, 30 (1985), pp. 35-46. See also J. Mishra, "Managing the Grapevine", Public Personnel Management, I9 (1990), pp. 213-228. 
unhygienic work environment. The first joke implies that while the workers must lie to the inspectors about their working conditions, they choose joking as the medium to express their cynicism and disenchantment at the rhetoric of social responsibility coming from their employers. Besides conveying a serious message about the reality of the shopfloor, where workers are often taken ill, the second joke strengthens the relationship not only among workers but also between workers and lower-ranking shopfloor management staff.

\section{MANAGEMENT BY THE QUOTA SYSTEM}

The fieldwork for this article took place in a garment workshop named $\mathrm{MH}$, a joint venture between a Vietnamese state-owned company and a South Korean multinational. Since its establishment, the workshop had produced only short trousers for the US market, but it should be noted that in general Vietnamese garment companies are not often direct providers to US, European, or Japanese customers, but usually have to deal with Asian middlemen, typically South Koreans or Taiwanese. In the case of $\mathrm{MH}$, the South Korean company acted as both investor and middleman. The garment industry is considered as one of the most important to the Vietnamese government, for garment export, along with the oil and fishing industries, not only earns high revenues but also, as a labour-intensive industry, creates a great number of new jobs in what is a highly populated country.

However, in order to be competitive in the international market and to be attractive to foreign investors, labour costs in the garment industry must be kept as low as possible, so labour relations in the garment industry can be considered a tense area. To prevent the import of commodities produced by mistreated labour, many US and EU customers often send independent international consulting companies to inspect working conditions in Vietnamese garment factories. If a garment company is found to have poor labour relations, its export activity to the US or EU will be stopped. In the case of $\mathrm{MH}$, the South Korean company hired inspectors to inspect $\mathrm{MH}$. One of the jokes is connected with the inspection.

The company was established only in 2002 and employed about I,000 workers. There were 8 production lines in the workshop, each equipped with the latest machines, and each with about soo workers. As a result, in comparison with less efficiently equipped workshops, automation gave high productivity, higher salaries (assuming of course similar piece rates), ${ }^{4}$ and easier working conditions, but the intensity of the job was rather more

4. In Vietnam, garment workers' wages are often based on the numbers of pieces they produce rather than the numbers of hours or days they work. 
severe in $\mathrm{MH}$ than it was in other local operations. That intensity was the main source of one of the jokes: workers did indeed collapse on the shop floor.

The most prominent management strategy was the quota system, which meant that a team or a production line must produce a certain quantity of products before they could go home that day; as a result, MH's workers did not leave the factory at some fixed time every day but at perhaps 8 or 9 o'clock at night and sometimes even later. Among the shopfloor management staff, besides the directors, there were two vice-directors, one in charge of productivity and the other of technology in the whole workshop. Among several garment workshops I investigated, only at $\mathrm{MH}$ was there a separate manager who supervised productivity. Division of labour among management staff reflected the company's special concern with productivity, and it should be noted that, although receiving foreign investment, the workshop had no foreign managers. ${ }^{5}$

Daily quotas, however, were not fixed at all. For example, from October to December 2002 the day production quota for Team 8 increased from 600 to 700 pieces. Management legitimized the increase by pointing out that the more workers got used to the products the faster they would produce them. At the same time, many workers complained that not only was the subcontract price lower for each piece, but that the time for one standard operation became shorter too. As an example, one worker said that she was assigned in October to an operation of only 3 lines and the standard operation time was fixed at I4 I seconds. In December, she had to do 4 lines at 90 seconds. In the end her salary remained the same, although she could work much faster because she had already got used to the operation. Workers were aware of that sort of manipulation by management in the measurement of unit labour costs, something that Peter Meiksins saw as an essential intervention of capitalism in the organization of work to exploit wage labour. ${ }^{6}$

Another management strategy was nhay chuyen, which translates literally as "jumping in the line". One can imagine the operation of a production line as a flow of water. If one person works much slower than the average line speed to the extent that the worker sitting in front has nothing to do, the foreman of the line will allocate an extra worker to the task to support him or her to catch up with the pace of the line. At the end

5. In the past, most of the wholly foreign-owned companies and joint ventures in the garment industries employed foreigners (mostly South Koreans and Taiwanese) as managers. However, because of the public outcry following several cases of labour conflicts between South Korean and Taiwanese managers and Vietnamese workers, the cause of which was often assumed to be cultural misunderstanding, some foreign companies now use Vietnamese managers instead.

6. F. Peter Meiksins, "Scientific Management and Class Relations: A Dissenting View", Theory and Society, I3 (1984), pp. I77-209, I85. 
of a batch, the workers had to calculate the total output for each task they had done in order to calculate wages. That innovation was designed to facilitate a smoothly running production line and was applied to individual workers to improve productivity of the line. Thus, deskilling which enables employers to apply daily quotas and nhay chuyen becomes a tool to justify their exploitation of workers. Subjectively, the workers experience a higher level of stress and strain as the job intensifies. Accidents sometimes occur, such as needles running through workers' fingers for, of course, job intensification is one of the things that tends to cause accidents; and because in $\mathrm{MH}$ the machines were automatic and set to run at high speeds, accidents occurred more easily; when they did occur, the resulting injuries could be serious.

When I asked one manager about SA 8000, ISO 9000, and ISO I 400 I, 7 he replied that the company was not bothered about obtaining those certificates because to do so would take time and money. That did not mean that $\mathrm{MH}$ did not follow the standard requirements in terms of techniques, working environment, and social policies. And accordingly, it was guaranteed work in the production chain of the South Korean multinationals. With regard to social policies, labour specialists hired by the customers came to check on and interview workers about working conditions at $\mathrm{MH}$. However, the workers were taught to tell lies in the interview. In the beginning, the foremen picked up some workers and told them not to say that they had to work on Sundays. Later, they were called to the manager's office for another round of "education" (in telling lies). The interviewees were even promised they would be given 50,000 Vietnamese dong ${ }^{8}$ for playing their part. ${ }^{9}$ At the same time, they were implicitly intimidated by being told that anyone who revealed what was going on would be sacked. It seemed that the labour specialists did not even choose workers randomly from the shopfloor, but interviewed only those already sitting in the manager's office waiting for them. So the company could easily make arrangements in advance.

\section{TWO JOKES A T MH}

In the literature on management, humour is considered to be something that management has lost control over ${ }^{10}$ or which threatens the authority of managers and employers. However, to what extent humour is considered as a weapon of the employees in their struggle against management

7. SA 8000 is a standard and verification system for assuring humane workplaces, ISO 9000 is a generic name given to a family of quality management standards, and ISO I 400 I specifies the requirements for an environmental management system.

8. 50,000 Vietnamese dong is approximately US\$3.

9. This will be elaborated in the next part, where workers made jokes about the interviews.

ı. Gabriel, "Unmanaged Organization". 
and employers is still under debate. While humour refers to the quality of being amusing or comical, there is a range of activities which produce that response, such as jokes, cartoons, songs, and poems. In this article, I wish to explore the effect only of jokes and of telling jokes in organizations. However, no matter the forms of activity to convey the humorous message, humour is always connected with fantasy, myth, or things which are actually unreal.

In his study of the informal practices in an organization, Gabriel writes: "Fantasy can offer a third way to the individual, which amounts to neither conformity nor rebellion, but to a symbolic refashioning of official organizational practices in the interests of pleasure, allowing a temporary supremacy of emotion over rationality and uncontrol over control." ${ }^{\mathrm{II}}$ Talking about the role of myth in the individual construction of stories, Samuel and Thompson argue that myth and reality are not easy to distinguish when myths are part of created reality. In other words, a joke is constructed as a kind of organizational myth, based partly on reality and the engagement of more or less unconscious desires for outright resistance. ${ }^{\mathrm{I} 2}$ Studies of the informal practices of an organization consider humour as an individual form of resistance ${ }^{\mathrm{I} 3}$ and an act of Eigensinn ${ }^{\mathrm{I} 4}$ which does not fit into the binary logics of obedience nor resistance.

However, Samuel and Thompson do not explore the collective nature of such kinds of myths or stories. If jokes are considered as one kind of workers' misbehaviour, ${ }^{\text {IS }}$ Martinez and Stewart offer a different view:

I I. Ibid., p. 479 .

I2. Samuel and Thompson, Myths We Live By.

I3. The issue of subjectivity and resistance has been discussed in detail by several authors, including D. Knights, "Subjectivity, Power and the Labour Process", and H. Willmott, "Subjectivity and the Dialectics of Praxis: Opening up the Core of Labour Process Analysis", in D. Knights and H. Willmott (eds), Labour Process Theory (London, 1990), pp. 297-335 and 336-378 respectively. See also D.L. Collinson, Managing the Shopfloor: Subjectivity, Masculinity and Workplace Culture (Berlin, I992). The idea was also reflected in D.L. Collinson, "Managing Humour", Journal of Management Studies, 39 (2002), pp. 269-288.

I4. Marcel van der Linden, “Keeping Distance: Alf Lüdtke's 'Decentred' Labour History”, International Review of Social History, 40 (1995), pp. 285-294. According to Van der Linden, Eigensinn was first introduced by Alf Lüdtke, a German historian, to denote having one's own sense, self-willed behaviour, obstinacy, intractability, and pigheadedness. Resistance meant "strategically optimizing the effectiveness of behaviour", whereas Eigensinn signified joyful expenditure of time on the spot "without any calculation of effects or outcomes". Gabriel, "Unmanaged Organization", also argued that fantasy including humour provided a third possibility to organization members, which amounted to neither conformity nor rebellion but to a grudging material acceptance accompanied by a symbolic refashioning of events and official stories.

I 5. P. Thompson and S. Ackroyd, "All Quiet on the Workplace Front? A Critique of Recent Trends in British Industrial Sociology", Sociology, 29 (1995), pp. 615-633. In their article, Thompson and Ackroyd use the term "misbehaviour" to capture the full range of employee practices in the control-resistance model. Thus, jokes, which are considered as acts of neither obedience nor resistance, also belong to this range and hence can be called misbehaviour. 
jokes should not be understood only as individual practices in opposition to the collective formal institutions (teams, workshops, or companies) ${ }^{16}$ but also as the experience of individual employees working together, which can lead to a spectrum of collectively held orientations and narratives and the experience of an individual in relation to different collective social groups, such as workers, women, men, or managers. ${ }^{17}$ In other words, jokes should be analysed in their embedded contexts in order to see how and by how much they reflect the collective reality of the workplace as well the collective desires of the workers.

Further, in the direction of collectiveness in the traditional sense, story work is not an individual matter. ${ }^{18}$ It is a process involving several individuals. In a way, the exchange or transmission of such reality and desires can influence the ties among a group of people. In the case of music, sociologists have often demonstrated how locally produced music interacts with the "local structure of feeling". ${ }^{\text {I9 }}$ Such an understanding crucially informs the notion of collective identity and community in given regions and localities. There is then a connection between the growth of popular music and identity formation of a group of people. According to Frith, identity is mobile and our experience of music - music making and music listening - is best understood as an experience of this self in process. ${ }^{20}$

The point, of course, is not how a particular piece of music reflects people but how it influences them, how it creates and constructs an experience - a musical experience, an aesthetic experience - of which we can make sense only by taking on an identity both subjective and collective. Such an approach does not reject the connection between hearing music and the formation of an identity, but collective identities are born out of the sharing of some musical experience. The same thinking can be applied to the process of joke-making and sharing. Besides analysing the

I6. In the literature on human resource and management, collectivism is identified with formal institutions such as teams, workshops, or companies. See for instance J. Storey and N. Bacon, "Individualism and Collectivism: Into the I990s", International Journal of Human Resource Management, 4 (1993), pp. 665-684. However, L.M. Martinez and P. Stewart, "The Paradox of Contemporary Labour Process Theory: The Rediscovery of Labour and the Disappearance of Collectivism", Capital and Class, 62 (1997), pp. 49-79, refer to collectivism in the traditional definition of trade unions.

17. Martinez and Stewart, "Paradox of Contemporary Labour Process Theory".

I8. Samuel and Thompson, Myths We Live By, pp. 5 and 96.

19. See, for example, A. Bennett, Popular Music and Youth Culture: Music, Identity, and Place (Basingstoke, 2000), and S. Banerji and G. Baumann, "Bhangra 1984-8: Fusion and Professionalization in a Genre of South Asian Dance Music", in P. Oliver (ed.), Black Music in Britain: Essays on the Afro-Asian Contribution to Popular Music (Milton Keynes, 1990), pp. I37-I 33 .

20. S. Frith, "Music and Identity", in Stuart Hall and Paul Du Gay (eds), Questions of Cultural Identity (London [etc.], I996), pp. I08-I 27. 
desire for resistance underlying the jokes told in the various stories, we should pay attention to how jokes create and construct an experience from which collective identities are formed. It is not enough to analyse the content of the jokes; we must examine too the processes and embedded social contexts enabling them to be made and become popular.

\section{The first joke}

The story relates to the factory inspection by inspectors who have come to investigate how the company applied SA 8000 , a tool for assuring humane workplaces. After several workers had been called to the manager's office to undergo a short training course in how to answer questions for the SA 8000 interviews, one female worker told me the story of how they even made jokes about the interviews.

During lunchtime, we made fun of the interviews. I encouraged the girls to volunteer to be interviewed to get 50,000 dong to buy sweets. Suppose that we are asked if we have to work on Sunday, we will say "Yes" at once, but then scratch our heads and say "No". When we are asked whether we have to work until 9 pm, we will reply "Yes", but then scratch our heads and say "No". "How are the toilets?" "Wonderful." "Can you sleep over there?" "Yes, but before going to sleep, you have to take a deep breath." ${ }^{21}$

After telling the story, the girl added: "It is just for fun. We know very well that if we are not careful with our words, we will be sacked". Thus, the story can be considered as a joke because the girl and her friends were not the ones who were invited for the interviews, for, as mentioned above, only "decent" workers were picked by management for interview. Thus, the girls imagined many of the story's details, mostly the way they answered the questions, the way they played with the words "Yes" and "No" and the way they pretended to be stupid and unable to play their roles properly. It was true that inspectors visited the factory to investigate working conditions, and it was true that the management prepared for the interviews by selecting the interviewees and instructing them in how to answer questions and promised money afterwards as a reward; but we do not know if the inspectors asked the "right" questions. The girls might ask colleagues who had been interviewed about the questions they were asked, but they could just as easily make up the questions themselves.

So, although the line between reality and fantasy is very thin and blurred, what is more important is that the joke reflected another layer of collective facts about working conditions; working for more than twelve hours a day on normal working days, Sunday working without overtime, and the unhygienic state of the toilets. At the same time, one can see a

21. Interview with one female worker in MH's Team 8, Hanoi, I6 November 2003. 
collective desire, at least among this one group of the female workers at lunch together, to tell inspectors the truth about their working conditions. The joke can be considered as workers' misbehaviour or covert resistance.

\section{The second joke}

Workers at $\mathrm{MH}$ sometimes made jokes about physical exhaustion or collapse in the workshop. One day, Kiem, the vice-foreman of Team 8 , suddenly pretended to collapse. A nearby male worker promptly dragged him aside and to carry him away put him into a big plastic basket normally used for garments. ${ }^{22}$ Workers joked that it was the only way to take Kiem to the medical room because he was such a large man. One female worker told me how topical the joke was:

For a while, we had to work until so pm quite often. One day, several accidents occurred at the same time: one person had a finger pierced by a sewing machine needle, and two others had fingers cut by knives. Because they lost a lot of blood and were rather weak, they almost fainted. We brought them to the medical room for emergency treatment. The whole workshop was in uproar. Then we were allowed to go home at $9 \mathrm{pm}$. We told each other that if one more worker fainted, we could go home at $8 \mathrm{pm}$. Since then, management has not dared to ask us to work up to Io pm any more. The women fainted because they had to take care of their sick children the night before. The next day, they were so tired and sleepy at the end of the working day that they fell down and the needles ran over their fingers. ${ }^{23}$

Thus, by making the joke, Kiem hoped that managers might allow workers to go home early again. The woman who told me this story very much enjoyed the bit of drama that Kiem played. They even continued the joke by imagining that Cuc, who was a woman bigger and taller than the average girl in the workshop, also collapsed. This time, they would not lift a finger but call the fat man who was in charge of electricity to carry her to the medical room. But the outcome of the joke was only jolly laughs among the women.

In the second joke, the fantasy fabricated by the workers was very clear: the pretence of the vice-foreman in falling down and workers' flight of fancy about the collapse of a large lady. However, although of course entirely imaginary, that scene was rooted in reality. Accidents really happen during work at $\mathrm{MH}$, and the intensification of work and late working are certainly the main reasons for them. As in the first joke, there

22. Workers put their output (especially at the end of the production line, when products are almost completed and become bigger than those at the beginning of the line) in the big basket so that the products will not fall on the floor and be dirtied and so that workers on the next task can receive their work pieces easily.

23. Interview with one female worker in MH’s Team 8, Hanoi, , $о$ December 2003. 
was an intention to blur the line between reality and fantasy as well as between the overt aim of having a bit of fun on the spot and the covert aim of telling the truth about conditions in the workshop.

Besides the desire to tell the truth, there was the desire to change management's rule in favour of the workers, so the joke can be seen as an act of overt resistance. However, because of some hidden agenda concerning the calculation of risks and costs involved, the workers, who were in a weaker bargaining position, dared not resist management directly. In the next part, I shall briefly describe the social context to explain why workers preferred to take an indirect rather than a direct path of resistance.

\section{TRADE UNION AND OPEN LABOUR CONFLICTS}

The Vietnamese trade union can be considered as a variant of the Leninist model, with a dual role performing two sets of functions, the first concerned with the mobilization of labour production, and the second with the protection of members' rights and interests. Inherent in the model is a bias towards the mobilization of labour production, and against defence and representation, let alone promotion, of workers' interests as understood by Westerners. The functional bias stems directly from the concepts of "interest" that underlie this dualism, for since no "antagonistic" social conflicts can exist within a socialist society, neither can any fundamental schisms divide the working population, as employees, from the state, as employer. ${ }^{24}$

The Vietnam General Confederation of Labour (VGCL) is organized under Mat tran to quoc Vietnam (Vietnam Fatherland Front), an umbrella organization that includes all mass organizations in Vietnam. The Vietnam Fatherland Front is led by the Communist Party of Vietnam, so unofficially the VGCL is considered to be controlled by the party. ${ }^{25}$ The VGCL is the largest mass organization in terms of membership, having seventeen component industrial unions representing the various industries or professions. Alongside the national industrial unions are

24. A. Pravda and Blair A. Ruble, Trade Unions in Communist States (Boston, MA, I986), pp. I-2I.

25. Irene Nørlund, "Labor Laws and the New Labor Regimes: A Comparison of Vietnam and China”, in Björn Beckman, Eva Hansson, and Lisa Román (eds), Vietnam, Reform and Transformation (Stockholm, 1997), pp. I 59-178; A. Chan and I. Nørlund, "Vietnamese and Chinese Labour Regimes: On the Road to Divergence", The China Journal, 40 (1998), pp. I73197, also accessible at http://rspas.anu.edu.au/papers/ccc/AC_IN_labour_regimes.pdf (last accessed 3 I May 2007). For example, the role of the VGCL and its relationship to the partystate are set out in the Constitution, the Labour Code, and the Trade Union Law. The VGCL as a component of the party-state structure is referred to in Article ro of the Constitution. The dual role and its participation in state management are also outlined in Article 2 of the 1990 Trade Union Law. 
fifty-three provincial or city federations, while at the grassroots level the union is organized within each enterprise. According to the official scheme, the unions at different levels cooperate with the party and government at the corresponding level, but in fact a union at the grassroots level may work with both its corresponding provincial- or city-level VGCL and one of the seventeen national trade or professional unions to which it is affiliated. In some grassroots-level unions, the leaders claimed that they were organized directly under the local People's Committee. ${ }^{26}$

There have been a number of changes in the role of trade unions as a result of economic reforms. In the pre-reform system, trade union leaders participated in management, together with party officials, directors, and leaders of the Youth Union, but from the mid-I990s the old system of "collective management" was abolished. Managers or directors were no longer obliged to consult with other parties and were held solely responsible for the performance of their production units. ${ }^{27}$ Before the Đối mói economic reforms of the mid-I980s, trade unions played an important part in distributing social welfare such as housing allocations, in determining access to schools and kindergartens, and in managing pensions, unemployment benefits, and medical benefits. They also arranged social activities and holidays, bought gifts for birthdays and weddings, and visited the sick.

Membership of trade unions gave automatic access to social security, which made entry into the union a condition rather than an option. ${ }^{28}$ After the economic reforms, the role of trade unions as welfare distributors decreased. The VGCL took on a new role, checking, in collaboration with the local People's Committee, the implementation of the Labour Code at the local level. In many companies, even foreign-backed ones, union membership was a must. ${ }^{29}$ While trade unions were not actually a threat to management, companies would be heavily fined if it was found that there was no trade union organized within their enterprise. That was especially

26. E. Hansson, "Authoritarian Governance and Labour: The VGCL and the Party-State in Economic Renovation”, in Benedict J. Tria Kerkvliet, Russell H.K. Heng, and David W.H. Koh (eds), Getting Organized in Vietnam: Moving In and Around the Socialist State (Singapore, 2003), pp. I53-184, I57.

27. E. Hansson, "The Vietnam Railway Trade Union", in Beckman, Hansson, and Román Vietnam, Reform and Transformation, pp. I79-185, I8I.

28. Chan and Nørlund, "Vietnamese and Chinese Labour Regimes", p. 205; Hansson, "The Vietnam Railway Trade Union", pp. I60-16I.

29. During the first seven months of 1999,473 companies operating in Ho Chi Minh City were inspected (of which 35 were SOEs, while the rest were local private and foreign-backed companies). One of the committee's reports concludes that violations related to the signing of labour contracts, working hours, rest time, overtime payments, and the payment of social insurance are common problems in many private companies (local and foreign). However, only one of the 473 companies inspected did not have a trade union; Hansson, "The Vietnam Railway Trade Union”, p. I66. 
true of foreign-backed companies, in many of which trade unions were in fact dominated by the management. ${ }^{30}$

Trade unions in Vietnam do not normally negotiate wages. In the past, the wages of most employees were set by the government in a formal wage system, but nowadays a minimum wage system follows the "market", which treats each worker equally, irrespective of individual needs. ${ }^{31}$ In I999, the monthly minimum wage in the foreign sector was set at US\$ 45, while in the state sector it was as low as US\$ I $5 .^{32}$

In general, the implementation of the Labour Code was weak. Many workers, even trade union officers, were unaware of their rights and obligations under the Labour Code. There was still little understanding of the trade union's role within a market economy. Although labour disputes and conflicts became more frequent, the VGCL had no organization to deal with them. At grassroots level, unions dare not deal with the problem, nor were they competent to resolve conflicts. ${ }^{33}$

In most cases when a strike broke out, officials from the VGCL headquarters or from the provincial or city federations or the local People's Committee tried to conduct negotiations between workers and employers or to persuade workers to resume work, so that conflict was dealt with largely in an ad hoc manner, and mediation efforts generally involved workers, employers, union representatives, and local governments, with a representative of strikers usually involved in the process. Strikes might be backed by informal labour associations. Indeed, in many companies the presence or absence of a formal trade union had little impact on whether or not a labour dispute would result in a strike, and even when a strike did occur trade unions had nothing to do with its organization.

Even as the number of strikes increased dramatically every year, most of them were considered illegal because they did not follow the procedures stipulated by law. In I993, before the right to strike was sanctioned by law, in a statement to the Seventh VGCL National Congress the then president of the Confederation used the term "collective actions against management" to replace the word "strikes". The unions generally characterized strikes as "spontaneous reactions", denying the possibility of organization behind them, although some trade unions admitted that strikes were normally an undesirable part of a market economy. One even claimed that

30. In the new economic zones such as Tan Thuan near Ho Chi Minh City, the zone's deputy manager is simultaneously the head of the zone's trade union. Under such a personnel set-up, it was likely that of the thirty-four enterprises in the zone the fourteen unionized foreign ones were likely to be management-dominated; Chan and Nørlund, "Vietnamese and Chinese Labour Regimes".

31. Nørlund, "Labor Laws and the New Labor Regimes", p. I7I.

32. Hansson, "The Vietnam Railway Trade Union", p. I6r.

33. Tran Thanh Ha, Nhin lai cac cuoc tranh chap lao dong tap the - dinh cong trong cac doanh nghiep co von dau tu nuoc ngoai: Nhung kien nghi va giai phap (Hanoi, 1999). 
all the strikes were illegal and the control of strikes must become stricter. He said: "We must create an environment for foreign investment and so strikes have to be stopped". 34

All my informants agreed on one thing: that the VGCL had never been involved in a strike, nor helped workers to arrange one. Their obvious knowledge of the labour market and the sort of arguments they presented, and their insistence on the VGCL's passive role in strikes, indicated that there was a state-imposed agenda embraced by the VGCL which made it reluctant to use strikes to redress workers' grievances, even when they were acute. That forced workers to rely on their own resources to settle disputes with their employers.

In spite of their weakness in organization and structure, the Vietnamese trade unions were increasingly autonomous from the party-state. Although the law was criticized for not giving enough attention to the protection of labour rights, including the right to organize strikes, the Labour Code opened some possibilities for workers to form their own unions. For example, taxi drivers in Ho Chi Minh City, after participating in industrial action and strikes, set up their own unions in 1996. The VGCL gave them moral support but no money.

Underlying the Labour Code there was an intention to make a clear distinction between "employer" and "employee", who had all previously been referred to as "working people". ${ }^{35}$ The right to strike was finally granted in the Labour Code, which was newly amended on 2 April 2002 (Labour Code of the Socialist Republic of Vietnam). Although workers had the right to strike, they must give two weeks' notice of any industrial action to allow time for mediation. In response to many ambiguities about the VGCL's independence, which could be found in the labour laws as well as at all levels of trade unions, workers took action themselves to protect their own interests against their employers. However, in most cases their activities have remained dispersed and unorganized.

At $\mathrm{MH}$, as with many joint ventures, a trade union was set up under the control of the company. Each team elected one trade-union cadre, with all the cadres working together through an employee in the personnel department who was considered to be the representative of the workers. In other words, a representative was chosen by the company's management board, not by the workers. While a trade-union cadre had no power in union decision-making at company level, they were the implementers of the company's welfare policy on the shopfloor, rather than the representatives of workers' interests in bargaining with management. Strikes therefore occurred as the result of workers' disappointments and anxieties,

34. Interview with Tran Thanh Ha, Legal Expert at the Legal Department of the VGCL, is September 1999, cited in Hansson, "The Vietnam Railway Trade Union”.

35. Nørlund, "Labor Laws and the New Labor Regimes". 
without the participation of the trade union. When labour conflicts happened, the trade union did not even act as mediator.

From its establishment until the time I visited $\mathrm{MH}$, a period of nearly two years, only two labour conflicts happened in the company, although neither of them could be considered legal strikes. In the first, workers in one team sent a letter to the personnel department to question the low piece-rates. Next day, because they had heard no response from the company, they decided to leave the workshop at 4.30 in the afternoon. Workers in the other teams followed suit. In the end, the company had to send somebody to talk to the workers, and they increased the current piece-rates a little. The reason for the second strike was that workers had to work for several Sundays continuously. On one Sunday, all the workers stopped work at 5 o'clock although they were not supposed to leave until 6. In spite of the fact that $\mathrm{I}, 000$ workers were standing inside the gate, the guard refused to open it until 6 o' clock.

After that incident, four workers who were the suspected ringleaders of the strike were threatened with dismissal, but after investigation they were simply suspended for ten days without pay and were required to write a sort of report of the event. Neither strike was organized by a trade union, and while the strikes did not have long-term effects, the individual workers who initiated them ran the risk of punishment, and that prevented workers from taking further collective action.

\section{JOKES IN THE WORKSHOP AND THE PERCEPTION OF COMMUNITY IN THE WORKSHOP}

It can be concluded that Vietnam does not have a vibrant upward labour movement. Most strikes are illegal and are neither led nor organized by a trade union. In such a context, studies not only of overt resistance but of covert resistance too on the shopfloor are important for understanding working-class solidarity and the perception of working-class members of the labour movement. Whether a collective action can happen or not depends on many factors rather than solely a strong perception of working-class identity among workers. In fact collective action does not even need a sense of membership to be realized. ${ }^{36}$ Because of some hidden agenda, or for practical reasons, covert resistance, although it can arise from a clear and strong perception of antagonism towards a class structure, cannot be transformed to become overt resistance or collective action. Nonetheless, it is interesting and important to see how covert resistance can foster the perception of working-class membership bridge, 1987). 
through its engagement in dialogue between workers and employers or managers.

While management was able to control strikes as they wanted, jokes proved to be the unmanageable part of the organization. Without leadership from the trade union, workers who participated in the strike would risk being sacked, so strikes did not prove to be a good method of struggle for many workers.

On the other hand, management could not punish workers for telling each other jokes. In the first joke above, when the worker pretended to forget the instruction from managers to lie to the inspectors, the worker might be blamed for being stupid or forgetful but not for intending to resist. Even when managers understood the meaning underlying the joke, they dared not punish the worker either severely nor even directly. In the second joke, while the workers focused on the funny detail of how to carry the large bodies of Kiem and Cuc from the workshop to the medical room, they did not forget to add an important detail to the story: workers collapsing on the shop floor.

Thus, the two jokes played double roles: making workers laugh and revealing reality. Although in the reality of daily working life the line between "them" and "us" is clear, in the jokes the workers made fun only of "us", without touching upon "them". However, it was an indirect way to talk about "them". These double meanings of the jokes blur the boundary between obedience and resistance and it is hard for management to evince a punitive reaction.

In strengthening the perception of community among the workers, the role of humour is no less important than the role of revealing reality. At $\mathrm{MH}$, humour reduced the tension at work, which could sometimes improve working performance. While workers felt more relaxed and worked better, the frequent exchange of jokes among them made them understand each other better and forged a sense of friendship. In spite of bad working conditions, many workers, especially younger ones, did not want to leave, because they felt very attached to each other. Humour was good for management as it cemented the commitment of the workers to the workshop.

However, management did not like humour in general because ultimately it had more destructive consequences than benefits. Although it is difficult to say that the jokes were the revolutionary tool of the workers, jokes could mobilize them to a certain extent in their struggle against management. The enjoyment of jokes went hand in hand with the enjoyment of expressing a desire for overt resistance. As with music, the transmission or exchange of jokes produces an aesthetic experience, which is made sense of only by taking on both a subjective and a collective identity. In referring to the collective identity, jokes actually served to foster the perception of community among the workers. 
This article has demonstrated collective reality as a material resource from which collective identity is taken. It has also shown the reality of the employers' violation of working conditions, the superficial inspection of working conditions, high job intensification, as well as the absence of an organization to support workers in their struggles. 